\title{
A META-ANALYSIS OF THE PREVALENCE OF CLINICAL MANIFESTATIONS OF CHIKUNGUNYA VIRUS DISEASE IN BANGLADESH
}

\author{
FARHA MUSHARRAT NOOR ${ }^{1}$, MD BELAL HOSSAIN² ${ }^{2}$, QUAZI TARIKUL ISLAM ${ }^{3}$
}

\begin{abstract}
Background: Chikungunya is known as a mosquito-borne viral disease. It is transmitted to the human body by infected mosquitoes and caused different symptoms. The main aim of this study was to investigate the percentage of Chikungunya virus disease (CHIKV) patients who would had different clinical features at the acute or sub-acute stage of this disease in Bangladesh.

Methodology: In this meta-analysis, PubMed Central and BanglaJOL had been searched. Total 8 eligible studies had been selected for quantitative analysis. The pooled prevalence (PP) was used as effect measure to find the number of patients who would had different symptoms at acute or subacute stage of CHIKV disease. The pooled prevalence and 95\% confidence interval (CI) had been calculated using random effects model. To measure the presence of heterogeneity Cochran chi-square test was used and $I^{2}$ was used to quantify the heterogeneity.

Result: This meta-analysis indicated significant association between CHIKV disease patients and fever was [PP: 0.99; $p$-value $=0.00]$, joint pain [PP: 0.95, $p$-value $=0.00]$, rash [PP: 0.55, $p$-value = $0.00]$, joint swelling [PP: 0.38, p-value $=0.001]$, headache [PP: 0.48 , p-value $=0.007]$, pruritus [PP: $0.37, p$-value $=0.001]$, myalgia [PP: 0.62, $p$-value $=0.00]$, co-morbidity [PP: $0.56, p$-value $=0.001]$ at the acute stage of the disease and joint pain persists $>1$ month [PP: 0.50, p-value $=0.001]$ at the subacute stage of this disease.
\end{abstract}

Conclusion: In this meta-analysis ever, joint pain were found as most frequently occurred symptoms at the acute stage of CHIKV disease.

Keyword: Chikungunya virus disease, clinical symptoms, meta-analysis, acute-stage, sub-acute stage.

Received: 05 November 2018

Accepted: 20 January 2019

DOI: https://doi.org/10.3329/bjmed.v30i2.41533

\section{Introduction}

Chikungunya is an infectious disease, caused by infected mosquitoes (alpha virus family). This virus was first identified in Africa in 1952 and in Asia in 1960. 1,2 Aedes aegypti mosquitoes is the main vectors of Chikungunya in Bangladesh. ${ }^{3}$ It is basically a RNA virus. The name "Chikungunya" has been derived from kimakonde language, meaning that "to become controlled". ${ }^{1}$ Chikungunya has been established its presence more than 60 countries of the world. ${ }^{1}$ Chikungunya is self-remitting disease. More than 92$96 \%$ patients have developed symptoms after mosquito bite. ${ }^{4,5}$ Most of the common symptoms are fever, joint pain, rash, headache, myalgia, oral ulcer, muscle pain etc. 3,6 and those symptoms are fully cure after few days onset of the disease, but symptoms such as joint pain or arthritis may be persist for several months or sometimes several years. The disease has a long-term effect on the patients. Female patients and individuals whose age more than 40 years have more risk to develop long-term effect after CHIKV disease. ${ }^{7,8}$ Three stages have been classified according to the persisting time of symptoms; acute stage $(<3$ weeks onset of the disease), sub-acute stage (3 to 12 weeks) and chronic stage (> 12 weeks). ${ }^{9}$

In 2008, the first recognized outbreak of chikungunya in Bangladesh was identified in Chapainwobabgong, Rajshahi, the northwest area of the country and 32 cases were identified. ${ }^{10}$ The $2^{\text {nd }}$ outbreak had been occurred in sathiya upozila Pabna in 2009. ${ }^{11}$. In late October 2011, an outbreak of fever and severe joint pain was reported by a local health office in Dohar sub-district in Dhaka and 196 cases were identified. ${ }^{12}$ In 2012 an outbreak of chikungunya had been reported in the village of palpara in Tangail district and 364 individuals had been reported with this disease. ${ }^{13}$

1. M.Sc. Thesis Student, Department of Statistics, University of Dhaka, Dhaka 1000, Bangladesh.

2. Associated Professor, Department of Statistics, University of Dhaka, Dhaka 1000, Bangladesh.

3. Professor \& Head, Department of Medicine, Popular Medical College, Dhaka 1205, Bangladesh.

Address of Correspondence: Dr. Farha Musharrat Noor, M.Sc. Thesis Student, Department of Statistics, University of Dhaka, Dhaka 1000, Bangladesh (Result published), Cell: +8801521-569017, Email: farha90932@gmail.com.

Bangladesh J Medicine 2019; 30 : 71-77 
About 13176 clinically confirmed cases in 17 out of 64 districts were identified by Ministry of Health in April 1, 2017 to September 7, 2017.14 More than a million of people in Dhaka city were at risk of infection with Chikungunya. ${ }^{15}$

Bangladesh have a high risk of developing this disease. ${ }^{16}$ For 2017 epidemic of CHIKV disease, patients were monitored by Institute of Epidemiology, Disease Control and Research (IEDCR). Patients were confirmed for CHIKV disease on the basis of RT-PCR (Reverse transcription polymerase chain reaction) test in IEDCR. 14,16,17 Chikungunya virus disease has appeared as one of the major public health problem in Bangladesh, because a large proportion of population were affected by this disease. It has become a significant economic and medical burden for Bangladesh. This disease is also associated with the reduced quality of life of the affected people, because of clinical manifestation at the acute stage of the disease. ${ }^{16}$ In this study it is interesting to find out the proportion of patients who would had symptoms at the acute or sub-acute stage of this disease.

\section{Search strategy}

Relevant articles were searched from PubMed Central and BanglaJOL up to July 2018 to identify different symptoms at acute or sub-acute stage of CHIK disease for Bangladeshi patients. The search strategy was "Chikungunya" and "Bangladesh" and there was no time limitation to include data in the study. The search strategy was limited to the articles which were written in English language, studies only for human and studies conducted in Bangladesh. All the studies were screened by title and abstract to identify the eligible studies for this meta-analysis. Cross-sectional studies, case-series studies, cohort studies, follow-up studies were considered for this meta-analysis. Complete search strategy of this meta-analysis was showed in figure 1 .

\section{Study eligibility and selection}

Original articles with proportion of serology positive patients confirmed by diagnosis procedures such as RT-PCR (Reverse transcription polymerase chain reaction), ELISA (enzyme-linked immunosorbent assay) or IgM (Immunoglobulin $\mathrm{M}$ ) for CHIKV disease were included in this study. Studies were included in this analysis if the information of clinical manifestation of the patients at acute or sub-acute stage of CHIKV disease were available. Studies that included patients of CHIKV disease co-infection with other abroviral disease and duplicate articles were excluded.

\section{Statistical Analysis}

This meta-analysis was executed using statistical programming software $\mathrm{R}, 3.1 .1$ version with Meta package and Microsoft Excel spreadsheet. Pooled prevalence and 95\% confidence interval were calculated by random effects model to summarize weighted effect size along with each individual study. Random effects model was used because the prevalence of different studies were not same ${ }^{18}$. In the meta-analysis, Q statistic was used to find the presence

Flowchart of search strategy:

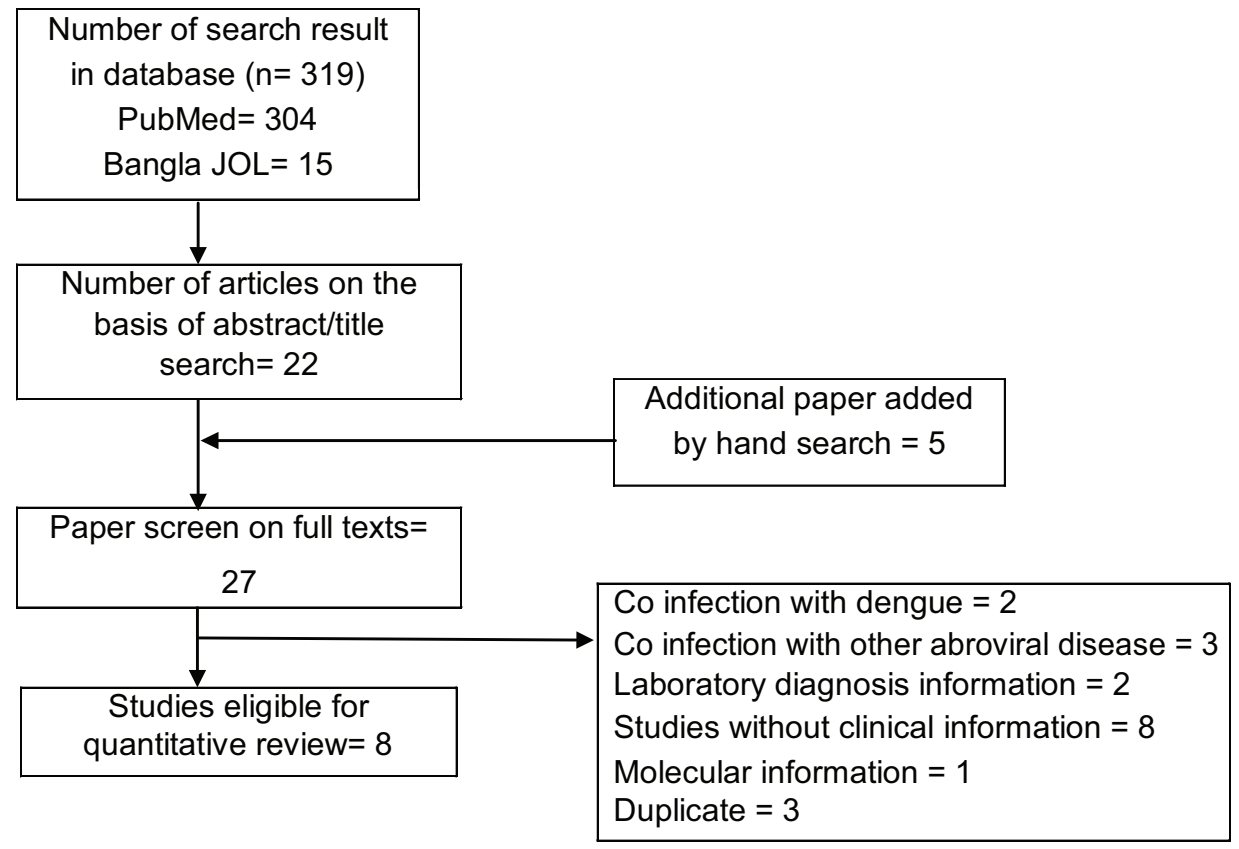

Fig.-1: Flowchart of search strategy to select eligible studies for this meta-analysis. 
of heterogeneity among the studies, was used to measure the percentage of variation across studies that arise due to heterogeneity and was used to measure between studies variance. Combining only the significant published studies had been lead to publication bias. That's why funnel plot was used in this meta-analysis to find publication bias among the included studies. ${ }^{19,20}$

\section{Result}

Total eight studies were eligible for our analysis of Bangladeshi patients in this article. Studies with CHIKV disease patients of different areas of Bangladesh were included in this analysis. Patients serologically confirmed for CHIKV disease were only included. Geological, demographical, clinical characteristics of the patients and total CHIKV disease patients $(\mathrm{N})$ were described in Table 1 and summary of the meta-analysis was described in Table 2. Graphical representation of the pooled prevalence of the variables were showed in figure 2. The pooled prevalence of CHIKV disease patients for fever was 0.99 [95\% CI: (0.96 -1.0), Zvalue $=46.29, \mathrm{p}$-value $=0.00]$, which indicates that 99 $\%$ CHIKV disease patients would had fever at the acute stage of the disease (Figure 2A), for joint pain [PP: 0.95, 95\% CI: $(0.92-0.98), Z$-value $=8.98, p$-value $=0.00]$, which indicates that $95 \%$ CHIKV disease patients would had joint pain at the acute stage of the disease (Figure 2B), for rash [PP: 0.55, 95\% CI: (0.41 - 0.68), $Z$-value $=7.79, p$-value $=0.00]$, for joint swelling [PP: $0.38,95 \%$ CI: $(0.16-0.59), Z$-value $=3.48, p$-value $=$ 0.001 ], for headache [PP: $0.48,95 \% \mathrm{CI}:(0.13-0.83)$, $Z$-value $=2.69, \mathrm{p}$-value $=0.007$, for pruritus [PP: 0.37, 95\% CI: $(0.15-0.59), Z$-value $=3.25$, p-value $=0.001]$, for myalgia [PP: 0.62, 95\% CI: $(0.55-0.70), Z$-value= 16.35, p-value $=0.00]$, for joint pain $>1$ month [PP:

Table-I

Characteristics of included studies.

\begin{tabular}{|c|c|c|c|c|c|c|}
\hline $\begin{array}{l}\text { Author, } \\
\text { Year }\end{array}$ & $\begin{array}{l}\text { Study } \\
\text { region }\end{array}$ & $\begin{array}{l}\text { Study } \\
\text { period }\end{array}$ & $\begin{array}{l}\text { Study } \\
\text { design }\end{array}$ & $\begin{array}{l}\text { Sample } \\
\text { size }\end{array}$ & Age, Gender & Main findings \\
\hline $\begin{array}{l}\text { Islam et } \\
\text { al., } 2017 \\
{[5]}\end{array}$ & $\begin{array}{l}\text { Dhaka } \\
\text { city }\end{array}$ & 2017 & Cohort & 257 & $\begin{array}{l}\text { Mean age }=43, \\
\text { Male }=90 \\
\text { Female }=167\end{array}$ & $\begin{array}{l}\text { Fever } 100 \% \text {, joint pain } 99 \% \text {, rash } \\
58 \% \text {, pruritus } 32 \% \text {, oral ulcer } \\
1.13 \% \text {, diabetes } 22 \% \text {, hypertension } 30 \% \text {. }\end{array}$ \\
\hline $\begin{array}{l}\text { Nazneen } \\
\text { et al., } 2018 \\
{[17]}\end{array}$ & $\begin{array}{l}\text { Dhaka } \\
\text { city }\end{array}$ & 2017 & $\begin{array}{c}\text { Cross- } \\
\text { sectional }\end{array}$ & 23 & $\begin{array}{l}\text { Male }=19 \\
\text { Female }=4\end{array}$ & $\begin{array}{l}\text { Comorbidities were presented } \\
\text { among } 96 \% \text { of the patients, fever } \\
100 \% \text {, joint pain } 39 \% \text {, rash } 21 \% \text {. }\end{array}$ \\
\hline $\begin{array}{l}\text { Hossain et } \\
\text { al., } 2018 \\
{[16]}\end{array}$ & $\begin{array}{l}\text { Dhaka } \\
\text { city }\end{array}$ & 2017 & $\begin{array}{c}\text { Cross- } \\
\text { sectional }\end{array}$ & 239 & $\begin{array}{l}\text { Mean age }=34 \\
\text { Male }=126 \\
\text { Female }=113\end{array}$ & $\begin{array}{l}\text { Comorbidities was presented } \\
\text { among } 74 \% \text { of the patients, } \\
\text { arthralgia } 100 \% \text {, rash } 78.2 \% \text {, } \\
\text { myalgia } 64.9 \% \text {, pruritus } 61.9 \% \text {, } \\
\text { headache } 69 \% \text {, joint pain } 198 \% \text {. }\end{array}$ \\
\hline $\begin{array}{l}\text { Rahim et } \\
\text { al., } 2017 \\
\text { [21] }\end{array}$ & $\begin{array}{l}\text { Dhaka } \\
\text { city }\end{array}$ & 2011 & $\begin{array}{l}\text { Case- } \\
\text { series }\end{array}$ & 7 & $\begin{array}{l}\text { Mean age }=39, \\
\text { Male }=4 \\
\text { Female }=3\end{array}$ & $\begin{array}{l}\text { Fever } 100 \% \text {, arthritis } 71 \% \text {, rash } \\
29 \% \text {. }\end{array}$ \\
\hline $\begin{array}{l}\text { Faruque } \\
\text { et. al. } 2017 \\
\text { [22] }\end{array}$ & $\begin{array}{l}\text { Several } \\
\text { area of } \\
\text { country }\end{array}$ & $\begin{array}{l}2008- \\
2009\end{array}$ & $\begin{array}{l}\text { Follow- } \\
\text { up }\end{array}$ & 10 & $\begin{array}{l}\text { Median age }= \\
35, \text { Male }=4 \\
\text { Female }=6\end{array}$ & $\begin{array}{l}\text { Fever } 100 \% \text {, joint pain } 100 \% \text {, } \\
\text { headache } 30 \% \text {. }\end{array}$ \\
\hline $\begin{array}{l}\text { Khatun et } \\
\text { al., } 2015 \\
\text { [12] }\end{array}$ & $\begin{array}{l}\text { Dohar } \\
\text { Dhaka }\end{array}$ & 2011 & $\begin{array}{l}\text { Case- } \\
\text { series }\end{array}$ & 196 & $\begin{array}{l}\text { Median age }= \\
35\end{array}$ & $\begin{array}{l}\text { Fever } 100 \% \text {, joint pain } 100 \% \text {, rash } \\
76 \% \text {, itching } 50 \% \text {, joint swelling } \\
29 \% \text {, headache } 12 \% \text {. }\end{array}$ \\
\hline $\begin{array}{l}\text { Hassan et } \\
\text { al., } 2014 \\
{[23]}\end{array}$ & Dhaka & 2012 & $\begin{array}{l}\text { Case- } \\
\text { series }\end{array}$ & 6 & $\begin{array}{l}\text { Mean age }= \\
39.5, \text { female }=6\end{array}$ & $\begin{array}{l}\text { Fever } 100 \% \text {, arthritis } 100 \% \text {, rash } \\
67 \% .33 \% \text { patients suffered from } \\
\text { joint pain }<2 \text { months after acute } \\
\text { infections. }\end{array}$ \\
\hline $\begin{array}{l}\text { HSB, } 2009 \\
\quad[10]\end{array}$ & $\begin{array}{l}\text { Rajshahi } \\
\text { and } \\
\text { Chapaina } \\
\text { wabganj }\end{array}$ & 2008 & $\begin{array}{l}\text { Case- } \\
\text { series }\end{array}$ & 39 & $\begin{array}{l}\text { Mean age }=39 \\
\text { Male }=19 \\
\text { Female }=20\end{array}$ & $\begin{array}{l}\text { Fever } 100 \% \text {, joint pain } 100 \% \text {, } \\
\text { myalgia } 62 \% \text {, rash } 39 \% \text {, oral ulcer } \\
8 \% .29 \text { patients still suffered from } \\
\text { joint pain for more than one } \\
\text { months after the recovery of fever. }\end{array}$ \\
\hline
\end{tabular}


Table-II

Summary table for random effect meta-analysis.

\begin{tabular}{|c|c|c|c|c|c|c|}
\hline \multirow{2}{*}{ Factors } & \multirow{2}{*}{$\begin{array}{c}\text { Pooled } \\
\text { prevalence } \\
(95 \% \mathrm{CI})\end{array}$} & \multicolumn{2}{|c|}{ Test for overall effect } & \multicolumn{3}{|c|}{ Test for Heterogeneity } \\
\hline & & z-value & p-value & Q statistic & p-value & $I$ \\
\hline Fever & $\begin{array}{c}0.99 \\
(0.97-1.00)\end{array}$ & 46.27 & 0.000 & 26.35 & 0.0002 & $77.2 \%$ \\
\hline Joint pain & $\begin{array}{c}0.95 \\
(0.92-0.98)\end{array}$ & 8.98 & 0.000 & 86.54 & 0.0001 & $91.9 \%$ \\
\hline Rash & $\begin{array}{c}0.55 \\
(0.41-0.68)\end{array}$ & 7.79 & 0.000 & 79.94 & 0.0001 & $92.5 \%$ \\
\hline $\begin{array}{l}\text { Joint } \\
\text { swelling }\end{array}$ & $\begin{array}{c}0.38 \\
(0.16-0.59)\end{array}$ & 3.48 & 0.001 & 76.54 & 0.0001 & $92.5 \%$ \\
\hline Headache & $\begin{array}{c}0.48 \\
(0.13-0.83)\end{array}$ & 2.69 & 0.007 & 507.2 & 0.0001 & $99.2 \%$ \\
\hline Pruritus & $\begin{array}{c}0.37 \\
(0.15-0.59)\end{array}$ & 3.25 & 0.001 & 133.83 & 0.0001 & $97.8 \%$ \\
\hline Myalgia & $\begin{array}{c}0.62 \\
(0.55-0.70)\end{array}$ & 16.35 & 0.000 & 2.51 & 0.285 & $20.3 \%$ \\
\hline Oral- Ulcer & $\begin{array}{c}0.13 \\
(0-0.33)\end{array}$ & 1.30 & 0.192 & 97.9 & $<0.0001$ & $98.7 \%$ \\
\hline $\begin{array}{l}\text { Joint pain } \\
>1 \text { month }\end{array}$ & $\begin{array}{c}0.50 \\
(0.22-0.79)\end{array}$ & 3.45 & 0.001 & 21.76 & $<0.0001$ & $90.8 \%$ \\
\hline $\begin{array}{l}\text { Co- } \\
\text { morbidity }\end{array}$ & $\begin{array}{c}0.56 \\
(0.22-0.91)\end{array}$ & 3.20 & 0.001 & 161.25 & $<0.0001$ & $98.8 \%$ \\
\hline
\end{tabular}

0.50, 95\% CI: (0.22 - 0.79), $Z$-value $=3.45, \mathrm{p}$-value $=$ 0.001 ], for co-morbidity [PP: 0.56, 95\% CI: (0.22- 0.91), $Z$-value $=3.20, \mathrm{p}$-value $<0.00]$. All the above results were statistically significant since $\mathrm{p}$-value is very small for all of those variables. However the pooled prevalence of CHIKV disease patients for oral ulcer was [PP: 0.13, 95\% CI: (0.00 - 0.33), $Z$-value $=1.30, p$-value $=0.192$ ], which indicates that $13 \%$ CHIKV disease patient would had oral ulcer at the acute stage of the disease but this result was not significant since $\mathrm{p}$-value is large.
Publication bias was investigated with a funnel plot for standard error (SE) by proportion for all the variable separately. Funnel plot was showed in figure 3. An evidence of publication bias were founded using funnel plot for variable fever, joint pain, rash, joint swelling, headache, pruritus, oral ulcer, co-morbidity, joint pain persists more than one months because some of the variables for those studies residing outside of the funnel. But no evidence of publication bias was founded for variable myalgia since all of the studies residing inside of the funnel.

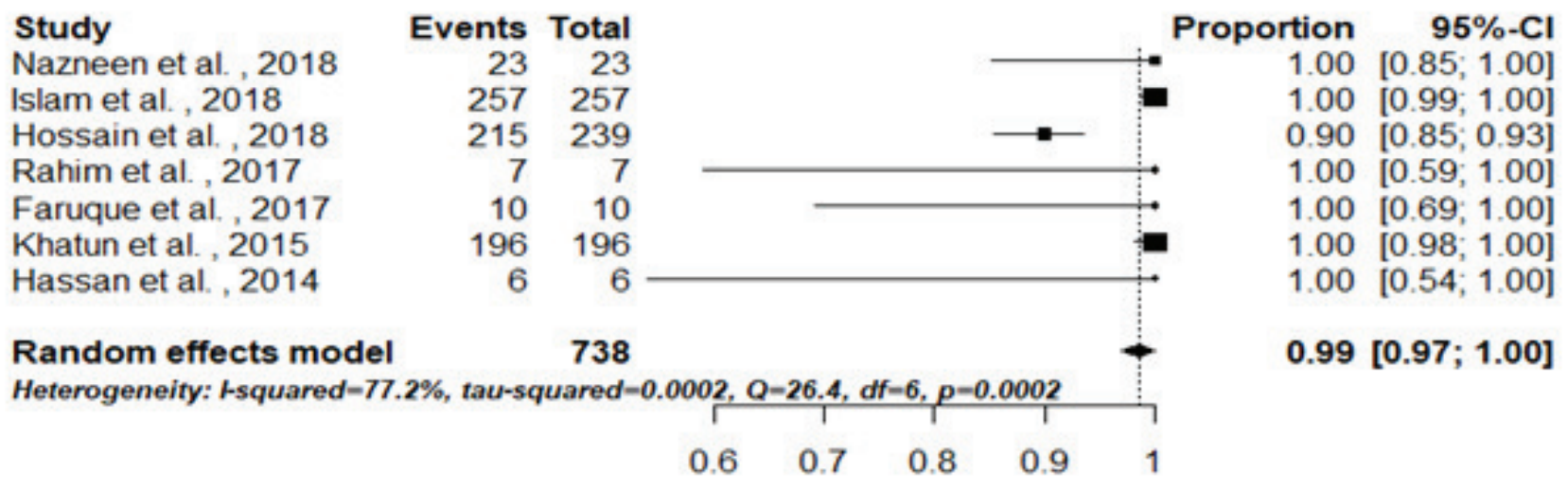

Figure 2A: Forest plot for variable fever 


\section{Study}

Nazneen et al. , 2018

Islam et al. , 2018

Hossain et al. , 2018

Faruque et al. , 2017

Rahim et al., 2017

Khatun et al. , 2015

Hassan et al., 2014

HSB, 2009

Random effects model

Heterogeneity: 1 -squared $\mathbf{9} \mathbf{9 1 . 9 \%}$, tau-squared $=0$.

\section{2}

Events Total
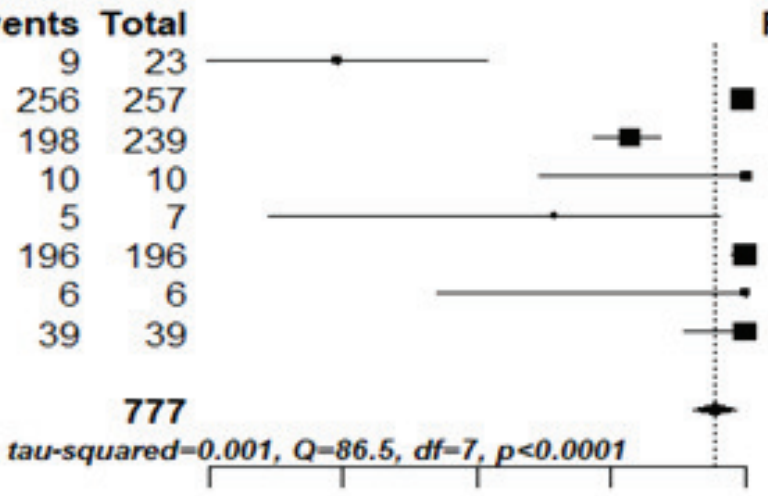

Proportion $\quad 95 \%-\mathrm{Cl}$

$0.39[0.20 ; 0.61]$

$1.00[0.98 ; 1.00]$

$0.83[0.77 ; 0.87]$

$1.00[0.69 ; 1.00]$

$0.71[0.29 ; 0.96]$

$1.00[0.98 ; 1.00]$

$1.00[0.54 ; 1.00]$

$1.00[0.91 ; 1.00]$

$0.95[0.92 ; 0.99]$

Figure 2B: Forest plot for variable joint pain

Figure 2: Forest plot for the prevalence of the clinical symptoms of CHIKV disease at acute or sub-acute stage of the disease in Bangladesh. Pooled prevalence along with all individual studies were showed in the plot with 95\% CI. Pooled prevalence estimates were presented with a diamond and individual studies were presented with a square. 2A, selected studies for variable fever. 2B, studies for joint pain. Forest plot had been also drawn for variable rash, joint swelling, headache, pruritus, myalgia, oral ulcer, Co-morbidities, joint pain> 1 month and shows a significant result for all variable except variable oral ulcer.
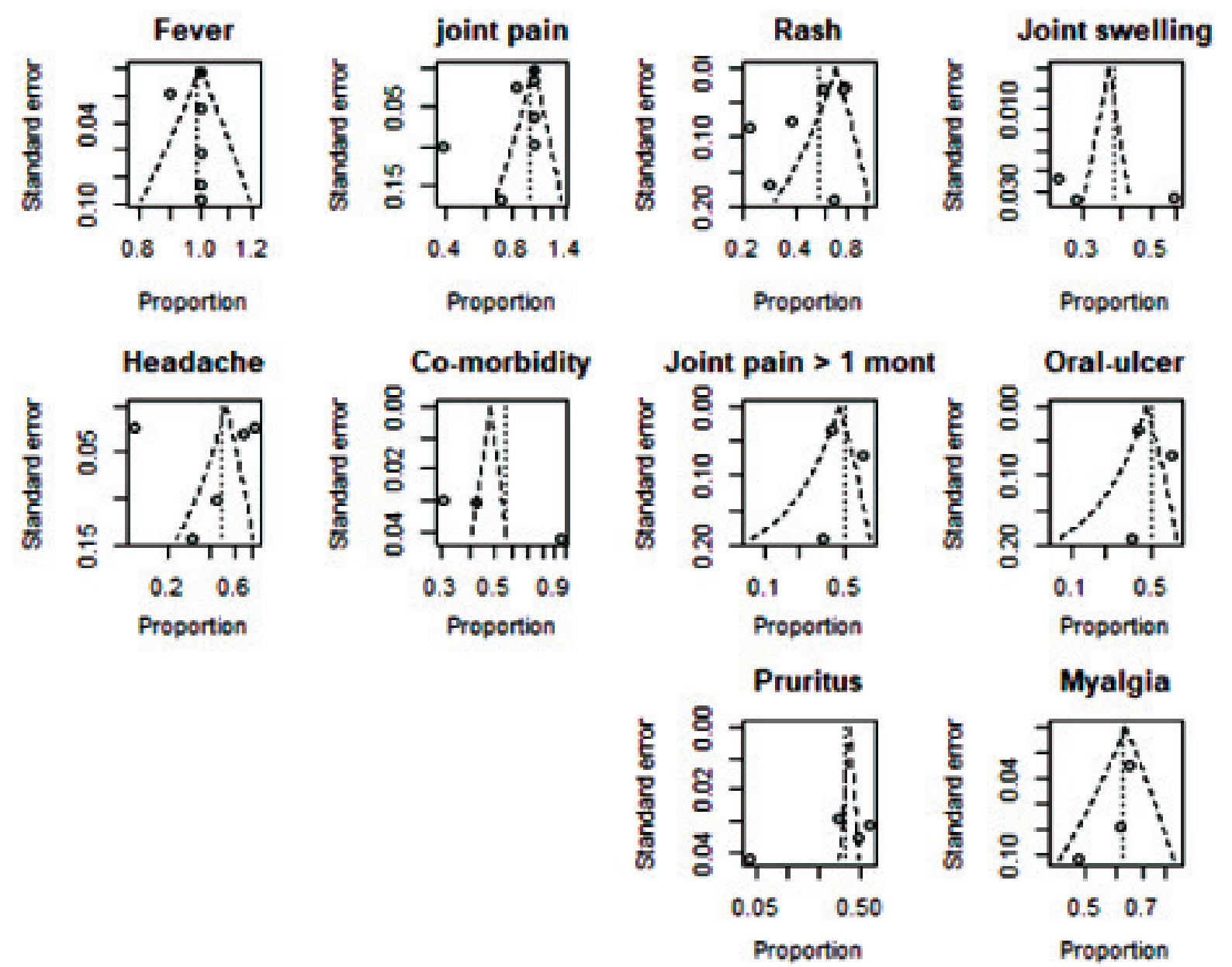

Figure 3: Funnel plot to detect publication bias in the data for all the considered variables. 


\section{Discussion and Conclusion}

In the recent years chikungunya virus disease seems to be a worrisome coming epidemic in Bangladesh. Bangladesh has a high risk of developing mosquitoborne disease, such as Chikungunya but less than Dengue and Malaria. Every year many individuals have been affected by this disease in Bangladesh. Aedes aegypti and aedes albopictus are considered as the main vector for the transmission of this disease in this region. ${ }^{3,12}$ Chikungunya virus disease has been usually emerged in Bangladesh after the rainy season. Different clinical symptoms such as fever, joint pain, rash, headache, joint swelling, pruritus, oral ulcer, vomiting, diahoria etc were found at the time of the outbreak of Chikungunya disease. ${ }^{3,6}$ The first outbreak of CHIKV disease was identified in 2008 in Bangladesh. ${ }^{12}$ But the outbreak of CHIKV disease in 2017 in Bangladesh breaks all the records of the past. On the report of Ministry of Health, more than 13176 clinically confirmed cases in 17 out of 64 districts were identified for this disease in 2017. ${ }^{14}$ According to the result of our meta-analysis, clinical symptoms such as fever, joint pain, joint swelling, rash, headache, pruritus were found as significant symptoms ( $p$-value $<0.01$ ) and oral ulcer was found as insignificant symptom ( $\mathrm{p}$ value $>0.01$ ) at the acute stage and joint pain persists more than 1 month was found as significant (p-value < 0.01) symptom at sub-acute stage of CHIKV disease patients in Bangladesh. Among all those symptoms, fever, joint pain were found as most frequent symptoms at acute stage of CHIKV disease. Chikungunya is not a life-threatening disease. Older people whose age is greater than 40 years, female patients and the patients having different comorbidities such as diabetes, hypertension, and cardiovascular disease have a high risk of developing this disease. ${ }^{7,8,17}$ More than 30\% patients have joint pain more than one months in the outbreak of 2011. ${ }^{13}$ This disease is diagnosed by RTPCR test in first week onset of the disease and IgM test between 5 days to 1 month onset of the disease. ${ }^{21}$ Those diagnosis procedures are highly expensive for most of the Bangladeshi people, so low cost diagnosis procedure should be invented for the affected patients.

\section{Conclusion}

As there is no appropriate vaccine to prevent this disease and medicine for the treatment of the disease, awareness of not being affected by this disease is the key word for it. Vector control is the most effective way to control this disease. Government and private agencies have already taken the challenge to control this disease in the city and rural areas of the country.

\section{References}

1. World Health Organization (WHO). Chikungunya, Bulletin, 2017.

2. Zeller H, Van Bortel W, Sudre B. Chikungunya: It's History in Africa and Asia and Its Spread to New Regions in 2013-2014. J Infect Dis. 2016 Dec 15; 214(suppl 5):S436-S440. https: / / doi.org/ 10.1093/infdis / jiw391.PMid:27920169
3. National Guideline on Clinical Management of Chikungunya Fever, DGHS. Ministry of Health \& Family Welfare, Bangladesh, May, 2017.

4. Thiberville SD, Boisson V, Gaudart J, Simon F, Flahault A, Lamballerie X. Chikungunya fever: a clinical and virological investigation of outpatients on Reunion Island, SouthWest Indian Ocean. PLoS Negl Trop Dis. 2013; 7, e2004.https://doi.org/10.1371/journal.pntd. 0002004.PMid:23350006 PMCid:PMC3547841

5. Islam QT, Majumder A. Basit A. Recent Clinical Experience with Chikungunya. Bangladesh Journal of Medicine. 2017; 28, 104-106. https://doi.org/ 10.3329/bjmed.v28i2.33361

6. Management of Chikungunya -a guideline, Bangladesh Society of Mediicne, May, 2017 (1st edition) P1-3.

7. Murillo-Zamora E, Mendoza-Cano O, TrujilloHernandez B, Guzmán-Esquivel J, Higareda-Almaraz E, Higareda-Almaraz MA et al. Persistent Arthralgia and Related Risks Factors: A Cohort Study at 12 Months from Laboratory-Confirmed Chikungunya Infection. Journal of Archives of Medical Research. 2018; 49(1), 65-73.https: / / doi.org/10.1016/j.arcmed.2018. 04.008.PMid:29703609

8. Sissoko D, Malvy D, Ezzedine K, Renault P, Moscetti F, Ledrans $\mathrm{M}$ et al. Post-Epidemic Chikungunya Disease on Reunion Island: Course of Rheumatic Manifestations and Associated Factors over a 15-Month Period. Journal of PLoS Neglected Tropical Disease. 2009; 3(3), e389. https://doi.org/10.1371/journal.pntd.0000389. PMid:19274071 PMCid:PMC2647734

9. Simon F, Javelle E, Cabie A, Bouquillard E, et al. French Guidelines for the management of chikungunya (acute and persistent presentations). Journal of Médecine et maladies infectieuses. 2015; 45, 243-263.https:// doi.org/ $10.1016 /$ j.medmal.2015.05.007. PMid:26119684

10. HSB. First identified outbreak of chikungunya in Bangladesh, 2008. Health Sci Bull. 2009; 7, 1.

11. Muaz SS. Chikungunya Fever: An Emerging Infection in Bangladesh. BANGLADESH J CHILD HEALTH. 2017; 41 (1), 1-3.https://doi.org/10.3329/bjch.v41i1.33627

12. Khatun S, Chakraborty A, Rahman M, Banu NM, Rahman MM, Hasan SMM, et al. An outbreak of chikungunya in rural Bangladesh, 2011. Journal of PLoS Negl Trop Dis. 2015; 9: e0003907. https:// doi.org/ 10.1371 /journal.pntd.0003907. PMid:26161995PMCid:PMC4498910

13. Amin R, Rahman M, Islam QT. Chikungunya. J MEDICINE 2017; 18: 92-108. https://doi.org/ $10.3329 /$ jom.v18i2.33687

14. Kabir I, Dhimal M, Muller R, Banik S, Haque U. The 2017 Dhaka chikungunya outbreak. The Journal of Lacent Infectious Disease 2017; 17(11), 1118..https:/ /doi.org/ 10.1016/S1473-3099(17)30564-9 
15. The Daily Prothom Alo. Chikungunya breaks out in epidemic form, Bulletin, 10th July, 2017.

16. Hossain MS, Hasan MM, Islam MS, Islam S, Mozaffor M, Khan MAS et al. Chikungunya outbreak (2017) in Bangladesh: Clinical profile, economic impact and quality of life during the acute phase of the disease. Journals of PLoS Negl Trop Dis. 2018; 12(6), e0006561. https: / / doi.org/10.1371/journal.pntd.0006561. PMid:29874242 PMCid:PMC6025877

17. Nazneen S, Saha M, Hossain R, Ahsan ASMA, Fatema $\mathrm{K}$, Ahmed F et al. Chikungunya Viral Infection Requiring Intensive Care - Experience in a Tertiary Care Hospital in Bangladesh. BIRDEM Medical Journal. 2018; 8(1), 16-20.https://doi.org/10.3329/ birdem.v8i1.35033

18. DerSimonian R, Laird N. Meta-analysis in clinical trials. Control Clin Trials. 1986; 7(3): 177-88. https://doi.org/ 10.1016/0197-2456(86)90046-2

19. Higgins J, Green S. Cochrane Handbook for Systematic Reviews of Interventions, 2008. https://doi.org/ 10.1002/9780470712184

20. Sutton AJ, Abrams KR, Jones DR, Sheldon TA, Song F. Methods for Meta-Analysis in Medical Research. John
Wiley \& Sons, LTD, Baffins Lane, Chichester, West Sussex, P019 IUD, England, 2000.

21. Rahim MA, Uddin KN. Chikungunya: an emerging viral infection with varied clinical presentations in Bangladesh: Reports of seven cases. Journal of BMC Res Notes. 2017; 10, 410. https://doi.org/10.1186/ s13104-017-2723-5.PMid:28810894 PMCid: PMC5558730

22. Faruque LI, Zaman RU, Gurley ES, Massung RF, Alamgir ASM, Galloway RL, et al. Prevalence and clinical presentation of Rickettsia, Coxiella, Leptospira, Bartonella and chikungunya virus infections among hospital-based febrile patients from December 2008 to November 2009 in Bangladesh. Journal of BMC Infectious Diseases. 2017; 17, 141.https://doi.org/ 10.1186/s12879-017-2239-6. PMid:28193163 PMCid:PMC5307764

23. Hassan R, Rahman MM, Moniruzzaman M, Rahim A, Barua S, Biswas R et al. Chikungunya - an emerging infection in Bangladesh: a case series. Journal of Medical Case Report. 2014; 8, 67. https://doi.org/ $10.1186 / 1752-1947-8-67$.PMid:24559283 PMCid:PMC3938320. 